\title{
“ON EDUCATION" IN A HIGHER SCHOOL
}

\author{
L.N. Anipkina, N.V. Shchennikova \\ Peoples' Friendship University of Russia (RUDN University) \\ 6, Miklukho-Maklaya str., Moscow, 117198, Russian Federation
}

This paper deals with a significant problem of education "outside" the classrooms. Authors present the methodological cases, using their pedagogical experience.

Much attention is paid in the article to specific practical assignments and examples of how best to organize extra-curricular activities of students. This paper is a presentation of a real year program for learners of RUDN University. It may be used in similar cases as its effectiveness is proved by numerous examples.

Key words: upbringing, educational case, extracurricular activities

The art of education is peculiar in that it is seen by almost everybody as familiar and transparent, even easy by some, and the less a person is experienced in it - either in theory or in practice - the more familiar and simple it appears.

K. Ushinsky

\section{INTRODUCTION}

The requirements to young professionals seem to be somewhat misbalanced nowadays. While professionally they are expected to respond to very high standards and to compete for best jobs, morally they are artificially unbounded: western ideology pushes them to discard ethical and moral norms which are part of the traditional Russian mentality.

In our view, the extracurricular work with students should be aimed at addressing this misbalance. As a prominent pedagogue K. Ushinsky put it, "Education should not only develop one's intellect and supply a certain amount of knowledge but also instil the desire of serious work, without which there could be no happiness in life".

The extracurricular work is aimed at forming a highly educated professional who is competent in the professional field and capable of uncovering his or her full potential, who is adapted to new social and economic situation, and who has a high cultural level, a firm civil position, and who is capable of adequately evaluate the degree of his or her social responsibility.

Needless to say, it is necessary to build a solid plan, to determine progress steps and to think through means and methods to achieve such an ambitious goal. With this in mind 
the Peoples' friendship university of Russia has elaborated a document called "Plan of action for implementing a program for raising competitiveness ('roadmap')" of the federal autonomous higher education institution "Peoples' friendship university of Russia". This plan (called below "the roadmap") for years 2016-2020 defines University's priorities: "Strategic goal of the Peoples' friendship university of Russia (RUDN University) is achieving world leadership position and establishing Russia's leadership in the domain of world class science and educational services in the interests of innovative social and economic development of the country, especially in the domain of international cooperation".

RUDN University's aspiration is to form "a world elite through unifying by knowledge people of diverse national, racial and religious backgrounds" on a basis of world class scientific and educational standards.

These formulas make obvious the complexity of the task and the need for an integrated approach to solving the problems which the University is facing.

The roadmap points out the favourable conditions created by the university to attract international students. The university has in place elaborated procedures for enrolment and education of foreign students; international students receive extensive support (housing, adaptation, entertainment etc.). The university plans to raise the percentage of international students to $40 \%$ by 2020 .

\section{DISCUSSION}

At RUDN University, the education of a modern professional is multi-level process: 1) International and federal level events; university events; 2) Faculty and cross-faculty events; 3) National groups' events (for foreign students); 4) Chair level events. This structure allows involving the entire student corps: even the least active students have chance to prove themselves.

RUDN has elaborated a plan with clear evaluation criteria according to which the chairs structure the extracurricular work with students. To motivate and support social activity of students and student unions, the University puts in place a structure of cultural events: festivals, parties, exhibitions, national culture and traditions events, international festivals of students. Intercultural cooperation trainings become more common. It is planned to broaden the activity of the Student council based on feedback received from students. The university organizes trainings for active students and team building events, involving representatives of national student associations (compatriot unions).

The process is guided centrally but it does not set boundaries to chairs' initiative. It becomes obvious when comparing the roadmap (its part dedicated to upbringing work, 2017 - first approved in 2015) to, for example, "The report of completion of the medium term development program, section V: extracurricular activity in the Faculty of social and humanitarian studies in 2013" (see Appendix 1 and 2). Even a small extract (the list of events is not at all limited to the above cited fragment) clearly demonstrates increased freedom, flexibility and transparency of content and goals of the events. It demonstrates a solid progress in educational work which came closer to students' interests, a shift of focus from pure entertainment to professional orientation and social activity. At the same time, traditionally popular events and activities are thoroughly protected and nurtured. 
Below we will look more closely into details of the extracurricular work at the Russian language and intercultural communication chair of the RUDN University.

Although the chair is not graduating, it has a lot of opportunities for organizing the extracurricular work. The course of Russian as a foreign language and teachers of the Russian language are well positioned for this kind of activity for a number of reasons:

- Foreign students form a separate group for the Russian language classes;

- The number of hours dedicated to Russian as a foreign language is high compared to other classes; the students spend more time with their Russian teacher which promotes mutual trust;

- Unlike lectures, the seminar format of the classes allows teachers receiving immediate feedback from students - both for teaching and extracurricular activity.

Each chair holds a position of vice-chairperson responsible for the extracurricular work. A teacher in this position, apart from her or his direct teaching role, is responsible for creating plans and reports of extracurricular activity and for organizing extracurricular events. Each event planned for the current year is assigned to a teacher for supervision. The plan is based on two main sources: 1) teachers' initiative related to their course (for example: a teacher of the course of Rhetoric would propose a round table dedicated to manipulation of conscience), and 2) feedback from students collected in a survey.

The upbringing process is by no means limited to extracurricular activity. Points 1.3a; $1.3 \mathrm{~B} ; 2.1 \mathrm{~B} ; 2.3 ; 2.46 ; 4.2$ of the Roadmap specify topics which are directly related to the curriculum and are part of the studies.

Below we site the Roadmap plan (the original table contains two extra columns, not shown here, which specify a responsible person for each activity and projected number of Russian and International attendants) (Table 1).

Roadmap: russian language and intercultural communication chair's plan of the extracurricular work with students of the faculty of social and humanitarian studies for 2017-2018

\begin{tabular}{|c|c|c|c|}
\hline & GOALS & EVENT NAME & $\begin{array}{l}\text { Date } \\
\mathrm{d} / \mathrm{m} / \mathrm{y}\end{array}$ \\
\hline $13 a$ & $\begin{array}{l}\text { Inclusion of the following topics in the curriculum } \\
\text { of humanitarian studies: History and geography } \\
\text { of Russia; history and geography of students' } \\
\text { countries of origin }\end{array}$ & & $\begin{array}{l}\text { Throughout aca- } \\
\text { demic year }\end{array}$ \\
\hline $\begin{array}{l}13 д \\
2.46\end{array}$ & $\begin{array}{l}\text { Organization and completion of trainings of com- } \\
\text { munication skills, conflict management, intercul- } \\
\text { tural communication and tolerance }\end{array}$ & $\begin{array}{l}\text { Round table on topic "Russian } \\
\text { proverbs on peace and freedom as } \\
\text { expression of tolerance in the Rus- } \\
\text { sian national character" }\end{array}$ & 12.09 .17 \\
\hline $\begin{array}{l}1.3 д \\
2.46\end{array}$ & $\begin{array}{l}\text { Organization and completion of trainings of com- } \\
\text { munication skills, conflict management, intercul- } \\
\text { tural communication and tolerance }\end{array}$ & $\begin{array}{l}\text { Inter-university student colloquium } \\
\text { "World languages and cultures. In- } \\
\text { ternational communication" } \\
\end{array}$ & 24.05 .18 \\
\hline $\begin{array}{c}1.3 \\
2.46\end{array}$ & $\begin{array}{l}\text { Inclusion of the following topics in the curriculum } \\
\text { of humanitarian studies: History and geography } \\
\text { of Russia; history and geography of students' } \\
\text { countries of origin } \\
\text { The number of Profession days (according to spe- } \\
\text { cialization) tied to professional celebration days } \\
\text { etc. }\end{array}$ & \begin{tabular}{|l|} 
Inter-university student colloquium \\
"World languages and cultures. In- \\
ternational communication"
\end{tabular} & 24.05 .18 \\
\hline $3.2 \mathrm{a}$ & $\begin{array}{l}\text { Percentage of first year students who participated } \\
\text { in lectures and excursions dedicated to the city of } \\
\text { Moscow (\% of total number of first year students }\end{array}$ & $\begin{array}{l}\text { Visit to the Russian museum of } \\
\text { popular and folkloric art. Moscow, } \\
\text { Tsvetnoy boulevard, Delegatskaya } \\
\text { str., } 3\end{array}$ & 17.03 .18 \\
\hline
\end{tabular}


Continuation of table 1

\begin{tabular}{|c|c|c|c|}
\hline & GOALS & EVENT NAME & $\begin{array}{l}\text { Date } \\
\mathrm{d} / \mathrm{m} / \mathrm{y}\end{array}$ \\
\hline $\begin{array}{l}1.3 \mathrm{~B} \\
4.2\end{array}$ & $\begin{array}{l}\text { Organization of professional competition for stu- } \\
\text { dents } \\
\text { Number of prizes won by students in different } \\
\text { competitions outside the University, including so- } \\
\text { cial and professional competitions and creative } \\
\text { competitions }\end{array}$ & \begin{tabular}{|l|} 
Training of foreign students of the \\
Faculty of Humanitarian and Social \\
studies for participating in student \\
Russian language Olympiad
\end{tabular} & $\begin{array}{l}\text { In a course of } 3 \\
\text { months in } 2018\end{array}$ \\
\hline 2.4 б & $\begin{array}{l}\text { Training as a form of active learning and transfer } \\
\text { of knowledge and skills }\end{array}$ & $\begin{array}{l}\text { Training dedicated to the Interna- } \\
\text { tional Translation day }\end{array}$ & 30.09 .2017 \\
\hline 2.4 б & $\begin{array}{l}\text { Training as a method of creating opportunities for } \\
\text { self-realization of participants and for independent } \\
\text { search of solutions for their own psychological } \\
\text { challenges. }\end{array}$ & $\begin{array}{l}\text { Training dedicated to the Interna- } \\
\text { tional tolerance day: "My attitude } \\
\text { towards UNESCO declaration of } \\
\text { principles of tolerance" }\end{array}$ & 16.11 .2017 \\
\hline 2.46 & $\begin{array}{l}\text { Training as a form of active learning and transfer } \\
\text { of knowledge and skills }\end{array}$ & $\begin{array}{l}\text { Training "Stereotypic reactions in a } \\
\text { conflict situation" for } 3-4^{\text {th }} \text { year } \\
\text { students }\end{array}$ & 28.02.18 \\
\hline 2.46 & Round table & $\begin{array}{l}\text { "Zoomorphic characters in Russian } \\
\text { and German culture" }\end{array}$ & 8.02 .2017 \\
\hline $2.4 a$ & $\begin{array}{l}\text { Number of meetings and master classes with Rus- } \\
\text { sia and world celebrities and prominent alumni }\end{array}$ & $\begin{array}{l}\text { Meeting Natalia Ufimtseva, head of } \\
\text { Ethnolinguistic department of the } \\
\text { Linguistics Institute of the Academy } \\
\text { of Science of Russia }\end{array}$ & 10.05 .18 \\
\hline $2.4 a$ & $\begin{array}{l}\text { Number of meetings and master classes with Rus- } \\
\text { sia and world celebrities and prominent alumni }\end{array}$ & $\begin{array}{l}\text { Meeting Anatoly Kim, a famous } \\
\text { writer }\end{array}$ & December 2017 \\
\hline $2.4 a$ & $\begin{array}{l}\text { Number of meetings and master classes with Rus- } \\
\text { sia and world celebrities and prominent alumni }\end{array}$ & $\begin{array}{l}\text { Meeting scientists from Germany, } \\
\text { USA and other countries (the final } \\
\text { list under construction) }\end{array}$ & Nov-Dec 2017 \\
\hline $\begin{array}{l}2.1 \mathrm{~B} \\
2.46\end{array}$ & $\begin{array}{l}\text { Faculty competition of students' projects } \\
\text { The number of Profession days (according to spe- } \\
\text { cialization) tied to professional celebration days } \\
\text { etc. }\end{array}$ & \begin{tabular}{|l|} 
Days of Slavic script \\
International conference of young \\
researchers "Languages and cul- \\
tures of the world" dedicated to the \\
Day of Slavic script \\
\end{tabular} & $\begin{array}{l}24.05 .18 \\
\text { May } 24,2018 \\
12.00-19.00\end{array}$ \\
\hline $\begin{array}{l}2.1 \mathrm{~B} \\
2.46\end{array}$ & $\begin{array}{l}\text { Faculty competition of students' projects } \\
\text { The number of Profession days (according to spe- } \\
\text { cialization) tied to professional celebration days } \\
\text { etc. }\end{array}$ & \begin{tabular}{|l|} 
Days of Slavic script. \\
Student fair "Samizdat"
\end{tabular} & 25.05 .18 \\
\hline 1.36 & $\begin{array}{l}\text { Interactive forms of teaching: } \\
\text { - project competitions; } \\
\text { - presentations, round tables (also dedicated to } \\
\text { topics related to foreign students' countries of } \\
\text { origin) }\end{array}$ & $\begin{array}{l}\text { Round table "Preparing for the ex- } \\
\text { amination session: how to work with } \\
\text { synopsis of lectures and articles, } \\
\text { lists of questions, examination top- } \\
\text { ics... Easy answers to difficult ques- } \\
\text { tions". }\end{array}$ & 01.06 .18 \\
\hline 1.36 & $\begin{array}{l}\text { Interactive forms of teaching: } \\
\text { - project competitions; } \\
\text { - presentations, round tables (also dedicated to } \\
\text { topics related to foreign students' countries of } \\
\text { origin) }\end{array}$ & $\begin{array}{l}\text { Watching and discussing a film } \\
\text { dedicated to the WWII, tied to the } \\
\text { Victory celebration day ("The } \\
\text { dawns here are quiet", "Only old } \\
\text { men are going to battle") }\end{array}$ & 04.05 .18 \\
\hline $1.3 a$ & & $\begin{array}{l}\text { Discussion with } 1^{\text {st }} \text { year students } \\
\text { "Students' rules of conduct. Stu- } \\
\text { dents' rights and responsibilities" }\end{array}$ & $\begin{array}{l}\text { Sep } 2017 \text {, within } \\
1-2 \text { weeks }\end{array}$ \\
\hline $\begin{array}{l}1.3 а \\
1.36 \\
1.3 д\end{array}$ & $\begin{array}{l}\text { Inclusion of the following topics in the curriculum } \\
\text { of humanitarian studies: History and geography } \\
\text { of Russia; history and geography of students' } \\
\text { countries of origin Interactive forms of teaching: } \\
\text { - project competitions; } \\
\text { - presentations, round tables (also dedicated to } \\
\text { topics related to foreign students' countries of } \\
\text { origin) }\end{array}$ & $\begin{array}{l}\text { A cycle of discussions "Tolerance } \\
\text { and political correctness as RUDN } \\
\text { standards" }\end{array}$ & $\begin{array}{l}\text { Sep } 2017 \text {, within } \\
2-3 \text { weeks }\end{array}$ \\
\hline
\end{tabular}


Анипкина Л.Н., Щенникова Н.В. Полилингвиальность и транскультурные практики. 2018. T. 15. № 3. C. $354-371$

Continuation of table 1

\begin{tabular}{|c|c|c|c|}
\hline & GOALS & EVENT NAME & $\begin{array}{l}\text { Date } \\
\mathrm{d} / \mathrm{m} / \mathrm{y}\end{array}$ \\
\hline & $\begin{array}{l}\text { Organization and completion of trainings of com- } \\
\text { munication skills, conflict management, intercul- } \\
\text { tural communication and tolerance }\end{array}$ & & \\
\hline 1.3д & $\begin{array}{l}\text { History and geography of students' countries of } \\
\text { origin }\end{array}$ & $\begin{array}{l}\text { Meeting of the student union "The } \\
\text { Professional, round table "The role } \\
\text { of the language in culture society" }\end{array}$ & $\begin{array}{l}20.09 .17 \\
\text { and } 22.09 .17\end{array}$ \\
\hline 1.36 & $\begin{array}{l}\text { Interactive forms of teaching: } \\
\text { - project competitions; } \\
\text { - presentations, round tables (also dedicated to } \\
\text { topics related to foreign students' countries of } \\
\text { origin) }\end{array}$ & $\begin{array}{l}\text { Round table "Linguistic image of } \\
\text { the world: "house" and "bread" per- } \\
\text { sonalities in Russian and German } \\
\text { culture" }\end{array}$ & 29.09 .17 \\
\hline $\begin{array}{l}1.3 \mathrm{a} \\
1.3 д\end{array}$ & $\begin{array}{l}\text { Inclusion of the following topics in the curriculum } \\
\text { of humanitarian studies: History and geography } \\
\text { of Russia; history and geography of students' } \\
\text { countries of origin Organization and completion } \\
\text { of trainings of communication skills, conflict man- } \\
\text { agement, intercultural communication and toler- } \\
\text { ance }\end{array}$ & $\begin{array}{l}\text { Discussion "'Who is the head of the } \\
\text { family in international marriage? } \\
\text { Raising children in mixed families: } \\
\text { problem of the language" }\end{array}$ & 12.10 .17 \\
\hline $\begin{array}{l}1.3 \mathrm{a} \\
1.36\end{array}$ & $\begin{array}{l}\text { History and geography of Russia; } \\
\text { Interactive forms of teaching: } \\
\text { - project competitions; } \\
\text { - presentations, round tables (also dedicated to } \\
\text { topics related to foreign students' countries of } \\
\text { origin) }\end{array}$ & $\begin{array}{l}\text { Video excursion "The Golden Ring } \\
\text { of Russia" (watching a film) }\end{array}$ & 17.10 .17 \\
\hline $\begin{array}{l}1.3 \\
1.3 a \\
1.36\end{array}$ & $\begin{array}{l}\text { Percentage of first year students who participated } \\
\text { in lectures and excursions dedicated to the city of } \\
\text { Moscow (\% of total number of first year students } \\
\text { Interactive forms of teaching: } \\
\text { - project competitions; } \\
\text { - presentations, round tables (also dedicated to } \\
\text { topics related to foreign students' countries of } \\
\text { origin) }\end{array}$ & $\begin{array}{l}\text { Visiting the "Peoples' friendship } \\
\text { museum" }\end{array}$ & 11.10 .17 \\
\hline $\begin{array}{l}2.1 \mathrm{~B} \\
2.46\end{array}$ & $\begin{array}{l}\text { Faculty competition of students' projects } \\
\text { The number of Profession days (according to spe- } \\
\text { cialization) tied to professional celebration days } \\
\text { etc. }\end{array}$ & $\begin{array}{l}\text { Literature competition dedicated to } \\
\text { a poet's birthday (Sergey Esenin } \\
\text { and others) }\end{array}$ & 18.10 .17 \\
\hline $\begin{array}{l}1.3 \\
1.36 \\
\end{array}$ & $\begin{array}{l}\text { Inclusion of the following topics in the curriculum } \\
\text { of humanitarian studies: History and geography } \\
\text { of Russia }\end{array}$ & $\begin{array}{l}\text { Round table "Historical background } \\
\text { of celebration of the concordance } \\
\text { and reconciliation day" }\end{array}$ & 15.11 .17 \\
\hline $\begin{array}{l}1.3 \mathrm{a} \\
1.36\end{array}$ & $\begin{array}{l}\text { Inclusion of the following topics in the curriculum } \\
\text { of humanitarian studies: History and geography } \\
\text { of Russia } \\
\text { Interactive forms of teaching: } \\
\text { - project competitions; } \\
\text { - presentations, round tables (also dedicated to } \\
\text { topics related to foreign students' countries of } \\
\text { origin) }\end{array}$ & $\begin{array}{l}\text { Watching a film "Seven walks } \\
\text { around Moscow" (topic "Tretyakov } \\
\text { gallery") }\end{array}$ & 22.11 .17 \\
\hline $\begin{array}{l}1.3 \mathrm{a} \\
1.36 \\
3.2 \mathrm{a}\end{array}$ & $\begin{array}{l}\text { Inclusion of the following topics in the curriculum } \\
\text { of humanitarian studies: History and geography } \\
\text { of Russia } \\
\text { Interactive forms of teaching: } \\
\text { - project competitions; } \\
\text { - presentations, round tables (also dedicated to } \\
\text { topics related to foreign students' countries of } \\
\text { origin) } \\
\text { Percentage of first year students who participated } \\
\text { in lectures and excursions dedicated to the city of } \\
\text { Moscow (\% of total number of first year students) }\end{array}$ & $\begin{array}{l}\text { A language and culture lesson: vis- } \\
\text { iting the State Tretyakov gallery } \\
\text { Moscow, Tretyakovskaya metro } \\
\text { station, Lavrushinsky lane., } 10\end{array}$ & 29.11.17 \\
\hline
\end{tabular}


End of table 1

\begin{tabular}{|c|l|l|l|}
\hline 3.2a. & \multicolumn{1}{|c|}{ GOALS } & \multicolumn{1}{|c|}{ EVENT NAME } & \multicolumn{1}{c|}{$\begin{array}{c}\text { Date } \\
\text { d/m/y }\end{array}$} \\
$\begin{array}{l}\text { in lectures and excursions dedicated to the city of } \\
\text { Moscow (\% of total number of first year students) } \\
\text { Inclusion of the following topics in the curriculum } \\
\text { of humanitarian studies: History and geography } \\
\text { of Russia; history and geography of students" } \\
\text { countries of origin }\end{array}$ & $\begin{array}{l}\text { Excursion to the Museum of De- } \\
\text { fence of Moscow or to Poklonnaya } \\
\text { memorial }\end{array}$ & 03.05 .18 \\
\hline 1.36 & $\begin{array}{l}\text { Interactive forms of teaching: } \\
\text { - project competitions; } \\
\text { - presentations, round tables (also dedicated to } \\
\text { topics related to foreign students' countries of } \\
\text { origin) }\end{array}$ & $\begin{array}{l}\text { Round table "Role of media in in- } \\
\text { ternational relations" }\end{array}$ & 24.12 .17 \\
\hline 2.3 & $\begin{array}{l}\text { Foundation of 3 professional student unions: work } \\
\text { of the unions "The Professional", "The Orator", } \\
\text { "Politician and Diplomat" }\end{array}$ & $\begin{array}{l}\text { Monthly sessions of the student } \\
\text { union "The Professional". First is } \\
\text { the organizational session. Agenda } \\
\text { for the sessions is co-created with } \\
\text { students during the first session ac- } \\
\text { cording to importance of the topics }\end{array}$ & 12.09 .17 \\
\hline
\end{tabular}

To control the chair's extracurricular work, instead of traditional paper reports the University has introduced a new format of a cross-chair competition review of achievement of roadmap annual goals. This format stimulates continuous improvement of this type of activity, encourages creative approach and increases involvement of both teachers and students.

The roadmap touches upon particularities of the upbringing work related to the international character of the student corp. "RUDN's specifics as a multinational university with students coming from 150 countries, concentrates on creating favourable conditions for a social and cultural adaptation of students to social and intellectual environment of the University, of the city of Moscow and of Russia".

In the past the University was offering to every student an introductory course of the Russian language. Currently, due to restructuration, modification of admission criteria and timing, and need to protect students' mobility, the students entering the first year of the bachelor's or master's program have different level of basic knowledge acquired in their countries of origin (from high school or college to bachelor's degree) and also a different level of Russian language skills. Among them there are students who have fully or partially completed the course of the preparation faculty of RUDN; those who graduated from preparatory courses in other Russian cities (Tula, Voronezh etc.); students who learned Russian in their native countries. Entrant students are also very diverse in what comes to their motivation for choosing the University and specialization:

- Entrant students whose family members are RUDN alumni who triggered their interest to studying in Russia and to RUDN in particular (A student from Nigeria: "My grandfather graduated from RUDN. He told me a lot about Russia and the University. He recommended me to enrol this University". A student from Colombia: "My uncle graduated from RUDN, now he's got a business in Moscow. When I graduate I'll get a job in his company".);

- Entrant students whose family members work in embassies of their countries or in Moscow offices of their national companies (A student from Bolivia: "My mother works 
in the embassy, I want a similar job, too. But I need a University diploma to get this job, this is why I have chosen to study International relations");

- Entrant students who have Russian family roots (a student from Syria: "My mother is Russian, when my father lived in Russia he married her and took her to Syria. At home we speak some Russian, so I decided it would be easier for me to study in Russia”);

- Entrant students whose interest was triggered by advice received from alumni, University advertising, attractive price;

- Entrant students sent by different organizations;

- In some cases, the interest is triggered by a sympathy to a charismatic persona ("I wanted to read Leo Tolstoy/Chekhov/Pushkin in their own language", "I love Stalin").

As we can see, there is a broad diversity in the student corps which proves that there is not only a need for educational work but also for a very detailed planning of diverse approaches. Which means that, while the end goal of this work remains the same, the ways of achieving it may greatly differ.

For example, familiarizing with the city of Moscow might be relevant mostly for the $1^{\text {st }}$ year students except those who already live in the city for several years (even though they might also need an update of the information they have acquired or changing their attitude).

It is no less difficult to achieve the goals set by roadmap for the work with students from a so-called "close foreign lands", i.e. from the countries which were part of the former Soviet Union. Entrant students from these countries might have only basic Russian language skills or even none at all; most of them make a lot of mistakes in written Russian and do not master the scientific style. Their attitude towards Russia as a "successor" of the USSR might be controversial, thus working with them requires a lot of attention. There is a need for a thorough, careful work of creating a positive image of Russia without hurting their national feelings; often this involves correcting the negative attitude through positive, learning-oriented activity.

It is a common wisdom in pedagogic that imposing ideas, slogans or one-size-fits-all solutions is not efficient and counterproductive. For that reason the goals should be achieved through creating a friendly, cooperative learning atmosphere, involving teams of students from different countries; through expressing interest in international students' native culture. Comparison might be a good method: by comparing and emphasizing similar positive mental patterns in Russians and foreigners we come to a conclusion that different nations have a lot in common. This does not mean that foreign students should not be familiarized with the original Russian culture and with traits of national character which are a source of national pride (the language in the first place and, closely related to it, popular counts, sagas; traditional fests with pagan origins and more modern ones; national traditions etc.).

To summarize the above points, the model "we are so different and proud of it" should be replaced with the model "we are different but we have a lot of common positive traits so we will easily understand each other".

At the University level this approach is formalized in legal acts. Anti-discrimination charts and University norms regulating the organization of work and cooperation of all divisions, teachers and student organizations during the learning process and in a dayto-day life, are the main tools for broadening the intercultural dialogue and to foster 
tolerance. It is also planned to elaborate and approve the Declaration of RUDN student community.

Below we look more in detail at several concrete activities of the Chair to share the experience of organizing different forms of events.

1. At a first glance, there might be no need for dedicating an entire session to introducing the University. The students are supposed to learn it all on their own! However, from experience we know that without this introduction session student's ideas about the University remain quite narrow and superficial. The session allows not only explaining a relatively complex University structure comprising many colleges, faculties and chairs, but also familiarizing students with carrier opportunities and showing perspectives of self-development on the base of several additional structures the University has. It is also important to show the history of the University, how it became a well-known brand, tell the students about prominent and successful alumni which will instil in students the sense of pride and belonging to a RUDN community. It is necessary to introduce the University newspaper "Friendship" and other information bulletins; explain how to work with computer classes and with other IT resources created to ensure a timely vertical information sharing (student - tutor, teacher, department) such as Study portal, Telecommunication learning information system aimed at constantly updating students on planned events and activities of other groups and unions. It is also important to create a positive setting to foster cooperation and creativity, demonstrate the advantages of active work. A valuable support to teachers can come from graduating students who should also be involved in the extracurricular work with new entrants as promoters and supporters capable of inspiring by example. It is beneficial for both recent entrants and graduating students who reinforce their sense of responsibility, and it will also strengthen vertical links between students of different years.

2. It is necessary to bear in mind that the extracurricular work's goal is not to entertain students or occupy their free time. It is a thoroughly planned and thought through activity aimed also at developing professional skills. Student professional unions created by the chair is an important tool for achieving this goal. As an example below we include a several month extract from working plan of one of them, "Politician and diplomat" (table 2).

Table 2

Working pean

\begin{tabular}{|l|l|}
\hline \multicolumn{1}{|c|}{ Date } & \multicolumn{1}{c|}{ Session topic } \\
\hline 21.09 .17 & "Discourse of power": introduction to political linguistic (format: roadmap) \\
\hline 05.10.17 & Basics of political communication (format: roadmap; discussion; presentation) \\
\hline 19.10.17 & Typological characteristics of political communication (format: case study) \\
\hline 02.11.17 & Text as a tool of influence (format: master class) \\
\hline 16.11 .17 & Diplomat's active dictionary (format: training) \\
\hline 30.11 .17 & Diplomacy: its mission and challenges of modern times (format: discussion; presentation) \\
\hline
\end{tabular}

Student professional unions' work is no substitute for regular classes: it plays a supportive and developing role; it helps better understand the theoretical information taught in classes due to the usage of concrete examples or by changing the prospective. Diverse formats of interactive learning help digesting the information and better memorizing it, 
add a creative element to the learning process, form skills of a joint co-creation of a scientific product: presentations, reports and even scientific publications. Besides, this form of activity offers opportunities for steady progress in achieving upbringing goals.

We would like to point out the diversity of upbringing activities. Besides traditional disputes, exhibition visits, excursions, new interesting formats are introduced:

- A search map. First ideas about using semantic networks in learning were introduced by American psychologist David Ausubel in 1960. He proposed that learning materials should help link new and already known information by comparing and uncovering links between the two. (http://tip.psychology.org/ausubel.html). Ausubel proposes to present general concepts in form of a flowchart with fundamental concepts placed in key points and arrows representing links between them. For each arrow it is specified what kind of link it represents (consequence, type, attribute, function etc.);

- Presentation/discussion. Combining these two formats can yield interesting results (work in progress);

- Case study. Harvard School of business was the first to introduce in 1908 case studies to learning process. In Russia this technology was introduced only in the past 3-4 years. It is a form of problem/situation analysis based on learning by solving concrete situations/ problems (cases). Its main goal is to boost the ability of finding a solution for a problem by analysing available information;

- Master class. It is a peculiar format of generalization and transfer of pedagogical experience. It is based on a thoroughly elaborated original method with its own principles and structured in a particular way. It is different from other format of experience transfer in that during master class occurs a real time discussion on the outcome; teaching master and students are all involved in a creative search for solution to a problem;

- Lexicographic training etc.

3. Let's look closely at one of these formats. We have already touched upon discussion as a form of teaching Russian as a foreign language. However, discussion as an extracurricular activity has some distinctive traits and is in many ways different from discussion as it is used in teaching Russian as a foreign language. Below we look at these traits in more details since many activities use this format according to the Roadmap:

The discussion was part of the learning process since antique times. Its goal, however, was to identify differences and find the truth in a process of exchanging ideas and opinions about a concrete topic between two or more people. This is reflected in the definition of discussion formulated by the dictionary "Political psychology": DISCUSSION (political dispute), from Latin discussion: consideration, research. A conversation on a predetermined controversial topic or unsolved problem with a goal of finding the share of truth in each of presented viewpoints and coming to a shared opinion.

For teaching foreign students the Russian language coming to a shared opinion is not relevant: the process itself, i.e. preparation and participation in the discussion is much more important. For a discussion as a form of extracurricular work the exact opposite is true. In this case the discussion is used with its original purpose and its form is secondary.

We have described in an article the difficulties which we faced when organizing a discussion in a group of students studying Russian as a foreign language. Analysing this experience we came to a conclusion that similar problems, mostly related to low student 
activity, may arise when organizing a discussion with upbringing goals. Below we briefly list these difficulties:

- Weak fact knowledge ("I didn't know what to say", "I was ill and couldn't prepare" etc. )

— Low general erudition ("the student X. Has already told it all", "they [other students] have already got it right without me");

- Weak language skills ( 'the student Y spoke too fast, I didn't understand anything", "It is difficult for me to say it in Russian"); me");

- Lack of ability to enter the discussion ("they spoke all the time and didn't listen to

- Traits of character ("I didn't want to interfere, they were saying all those very interesting things").

However, we also encounter new problems:

- Avoiding conflict ("I do not agree with X's opinion but I didn't want to argue")

Despite the differences, the requirements for preparative work remain high.

First, the teacher must select a topic which is:

a) interesting and relevant for all students taking into account their national traits (culture, religion, family values etc.)

b) sufficiently narrow, so that students could draw conclusions during a single session;

c) allowing for different points of view. It should not have a single straightforward solution.

Second, the preparation work is compulsory; under teacher's obligatory supervision students must select materials for an in-depth knowledge of the topic. The preparation may take a format of individual assignments for students, like reading an article selected by a teacher and making an extract or quotes from the article to support the argument etc.

Third, it is necessary to continuously teach the students special language clichés used in scientific or public speech (agreement/disagreement, assertiveness, hesitation etc.)

We have tried to introduce a number of practical tasks and assignments related to this work in the following text books: L. Anipkina "Russian language for sociologists" [1] and L. Anipkina, T. Romanova "Russian language for historians" A Russian language text book for foreign history (Medium Ages, History of Religion) students [2]. These exercises will help students enter the discussion in a more assertive way and conduct it is a stylistically correct manner. We used here some methods of creativity studies for a better effect [3-5].

Once the preparatory stage is completed, the discussion can be kicked-off. There also are several important points to pay attention to.

The teacher naturally takes the role of moderator, with the task of guiding the course of the discussion. The most important role of teacher in this process is to shift focus from the format of the discussion to following rules of political correctness and tolerance. The teacher should block all attempts of the participants to make the discussion personal. It is important for the teacher to avoid imposing her or his own point of view and correcting errors not related to miscommunication thus breaking the line of argument and the rhythm of the discussion. It is recommended to use, as a supportive material, a table into which the teacher will fill key discussion points which all participants can refer to. Teacher's goal is to involve all students in the discussion, to offer everybody an opportunity 
to speak up (hence it necessary to set a time limit for individual arguments, depending on the number of participants). The teacher also needs to make sure that the discussion comes to a logic conclusion and formulate key take-outs, if those are not formulated by students themselves.

Unlike the discussion used in Russian as a foreign language classes, the extracurricular discussion should not use a dedicated preparatory stage or the aftermath review.

When reviewing this type of activity (discussion) with students we established that it triggers the interest toward the topic ("thank you, it was very interesting", "shall we have more discussions on other topics?", "where did you find these materials, X? Please share the link, I want to read it through"); it raises motivation for further investigation of the topic and for active creative work ("Next time can I talk about... ?); sometimes it also leads to changing opinion after listening to opponents' arguments.

We can draw a conclusion that discussion is a very efficient type of interactive work and it is well worth the additional effort for its preparation and organization.

There are ideas to combine presentation with elements of discussion. It is expected that this approach, combining the illustrative presentation of materials with discussion interactions will raise the learning and upbringing efficiency (work in progress).

4. Another popular format of extracurricular activity is visits to exhibitions or musea. The Roadmap refers to it where it comes to familiarizing students with the city and with Russian culture. We have made several observations in this respect. Traditionally University's chairs organize events related to the anniversary of the victory of Russia in the WWII. In our chair, we organize a visit to the Museum of Defence of Moscow. This excursion always triggers interest of foreign students since they either just know dates of this historic event or nothing at all. First time when we visited the museum we ordered a guided tour, and the guide was warned about the specifics of the audience. But the museum employee decided by mistake that the excursion we needed was the same kind they organize for Russian high school students. Our students were averse to the "preaching" tone of the guide; the excursion was lengthy and overloaded with dates which lead to a fatigue. After analysing the mistakes of this failed experiment we decided that it would be more appropriate to guide the tour ourselves. First, the students are used to the tone and voice of their teacher who also only uses familiar vocabulary which makes it easier to digest the facts. Second, the teacher is capable to focus on those elements of exhibition which are in line with her or his educational goals (learning, corrective or emotional) for a concrete group of students. The teacher must trigger the interest of students by asking questions ("what would you do if you were in place of...", "what decision would you take in this situation..." etc.). Third, the teacher can monitor the fatigue of the students rather than talking through all dedicated timeframe as professional guides do. The fatigue caused by overload with excessive amount of information is counterproductive and might discard all positive effect of the event by creating a negative impression. Undoubtedly, this kind of work requires a thorough preparation: the teacher needs to know the facts, familiarize her or himself with the exhibition, both permanent and temporary, be ready to react quickly and answer "awkward" questions in a right way. However, despite the difficulties, this type of activity is fairly popular and yields good results as survey results and students' feedback prove ("I liked it very much...", "Thank you, it was very interesting...", "I didn't realize that...", "Can you please say again what was that book you recommended... about 
the war I mean"). We should also note that surveys on results - in diverse formats and level of details - are a must have component of any activity. They will not only reflect the emotional attitude of students but also will help checking the level of understanding. From students feedback the teacher will see whether the goals of the event were achieved.

5. The chair's quiz "Humourine" has always been very popular among students. This event, despite its pronounced entertaining character, sets important learning and upbringing goals. It both triggers the interest towards learning Russian and helps understand the humour of native Russian speakers. It is not always easy for foreigners to tell an innocent joke from insult when it is told to them or when they try to tell it in Russian.

The main amount of work is done during at a preparation stage. The first "homework" requires a particular teacher's attention. Most people use jokes in a day-to-day communication, in life, in learning or at work. A joke helps overcome a tension which might arise in a course of a dispute.

However, one should never forget that each person has a national mentality with all characteristic traits of that mentality, and different logics and mentalities can come into a conflict. Bearing this in mind is a necessary condition for successful communication between Russian and foreign students who represent very diverse cultures.

For that reason, when preparing foreign students for this task it is important to explain social and cultural traits of humour in students from different countries, explain how to avoid awkward situations and errors when telling jokes or reacting to other's jokes - both during the study in the University and also later, in professional communication.

These topics are covered in a discussion on characteristic traits of humour in different countries, in different social and cultural spaces.

There are psychological researches which answer the question: what is funny? Why some people understand the humour and other do not? Does the presence of the sense of humour depend on one's educational level?

Any good joke has an element of surprise at the end which triggers laugh. It is useful to note that Russian humour is mainly based on wordplay and pun rather than on a sense of superiority or abstract concepts. This makes it more difficult to translate Russian jokes into foreign languages or to explain their sense to a non-native speaker.

Although jokes might be a deviation from a neutral linguistic and sociocultural standard, and people often laugh at foreign cultures, this kind of jokes needs to be strictly avoided because it can be offensive for people with a different cultural background. Certain topics in certain countries may be an absolute taboo for jokes. Almost in any culture there are jokes about family relations. In Russian culture mocking the mother-in-law (wife's mother) is very common although jokes about husband's mother are practically nonexistent. But for the Vietnamese for example this kind of jokes might be offensive since a mother-in-low is one of the most respected Vietnamese family members. It is preferable to recommend students using neutral, non-personal jokes which cannot offend their companion and do not ridicule speaker's own country but just demonstrate a healthy sense of humour.

The format of the "homework" is also important. The attempts to make it similar to professional humourists' performance, where the jokes follow one another in cascade, failed since foreign spectators could not follow and understand the humour. A role play of comic scenes or anecdotes proved to be more successful. 
Other tasks of the quiz are mostly aimed at triggering students' interest to learning Russian. Examples of these tasks are included in the appendix.

6. Slavic script days - "Samizdat" fair - is a proud of our chair. It is organized under supervision of Professor U. Bakhtikireeva. Examples of students' work can be seen on chair's website.

7. A traditional event, warmly supported by students, is narrative competition dedicated to S.Esenin's anniversary. Its main goal is to familiarize students with Russian poetry and to demonstrate the characteristic traits of Russian mentality: love for the nature, proud for the native land, ability to see beauty in small things. An additional goal is to maintain succession between students of different years: graduating students who already participated in this event in the previous years, act as supervisors for first year's students when preparing for the competition.

According to the same principles it is planned to also include in the competition (or perhaps even organize a separate competition) reading of poems of foreign authors (translated into Russian). This allows discovering similarities between Russian and foreign mentality thus strengthening the educational effect of the event.

\section{RESULTS AND CONCLUSION}

In a conclusion we would like to name a key element of the extracurricular work: strictly avoiding any form of compulsion. Teacher's role is to create an atmosphere which triggers students' desire for participating in this kind of activity. This is a necessary condition for making the extracurricular work efficient and useful. We would like to emphasise the fact that, although the Roadmap introduces very useful elements of structuring and fostering the extracurricular activity, the end result must not be judged upon paper reports on a number of completed events. Even winning the inter-chair competition should not be seen as an extraordinary success story. Only creation of a positive image of the University and the country in a world educational and political space will be an ultimate prove of success of the extracurricular work.

\section{Appendix 1}

To the report of completion of the medium term development program, section V: extracurricular activity in 2013 (as per December 3, 2013).

Faculty of social and humanitarian studies

KPI 5.2. Number of events organized for students outside the University (visiting shows, theatres, exhibitions, galleries, scientific centres, laboratories etc.) and percentage of students who participated in these events (\% of the total number of students)

\begin{tabular}{|c|l|}
\hline № & \multicolumn{1}{|c|}{ Name of event } \\
\hline 1 & Visit to museum "Battle of Borodino" \\
\hline 2 & Visit to skating ring "Dynamo" \\
\hline 3 & Visit to museum of Ethnology and Anthropology of the Academy of Sciences of Russia \\
\hline 4 & Visit to a cinema, watching and discussing the movie "Les misérables" \\
\hline 5 & Visit to the exhibition "French clocks" in the State Museum of History \\
\hline
\end{tabular}

KPI 5.3. Number of excursions for students (including excursions to musea) and percentage of students who participated in these excursions ( $\%$ of the total number of students) 
Anipkina L.N., Shchennikova N.V. Polylinguality and Transcultural Practices, 2018, 15 (3), 354-371

\begin{tabular}{|c|l|}
\hline № & \multicolumn{1}{c|}{ Name of excursion } \\
\hline 1 & Excursion for foreign students to Yasnaya Polyana (Tula region) \\
\hline 2 & Excursion to Museum of Eastern art \\
\hline 3 & Excursion to museum estate of Leo Tolstoy \\
\hline 4 & $\begin{array}{l}\text { Excursion to Musum of Ethnography of the Institute of Ethnology and Anthropology of the } \\
\text { Academy of Sciences of Russia }\end{array}$ \\
\hline 5 & $\begin{array}{l}\text { Excursion to the State Tretyakov gallery. Exhibition of paintings and graphics from the collection } \\
\text { of the Kramskoy Art museum of the Voronezh region as part of the project "The Golden map } \\
\text { of Russia". Peter Nilus: "capturing the elusion" }\end{array}$ \\
\hline
\end{tabular}

KPI 5.4. Number of faculty lecture houses:

5.4.1. - on history and culture of peoples of the world;

5.4.2. - on topics of general culture and civil and patriotic topics.

\begin{tabular}{|c|l|}
\hline № & \\
\hline 5.4 .1 & \\
\hline 1 & Ethnology and problems of social evolution \\
\hline 2 & Actual problems of modern culture \\
\hline 5.4 .2 & \\
\hline 1 & role of personality in history \\
\hline 2 & Ethical problems in modern society \\
\hline
\end{tabular}

KPI 5.5. Number of Russian and foreign language Olympiads

\begin{tabular}{|c|l|}
\hline № & \multicolumn{1}{|c|}{ Name of Olympiad } \\
\hline 1 & Russian language Olympiad for foreign students \\
\hline 2 & Faculty English language Olympiad \\
\hline 3 & Faculty French language Olympiad \\
\hline
\end{tabular}

KPI 5.7. Number of professional student unions

\begin{tabular}{|c|l|}
\hline № & \\
\hline 1 & Student sociology bureau \\
\hline 2 & Club of Political consulting \\
\hline 3 & Study of Museology \\
\hline
\end{tabular}

KPI 5.8. Number of art and creative unions, circles, clubs, sport clubs, sport teams

\begin{tabular}{|c|l|}
\hline № & \\
\hline 5.8 .1 & \\
\hline 1 & Philosophy circle "Mosaic" \\
\hline 2 & Circle "Creative industry" \\
\hline 3 & Art union "The diamond of the Faculty" \\
\hline 5.8 .2 & \\
\hline 1 & Faculty team of athletics \\
\hline 2 & Faculty arm-wrestling team \\
\hline 3 & Faculty swimming team \\
\hline 4 & Faculty voetbal team \\
\hline 5 & Faculty volleyball team \\
\hline
\end{tabular}


Анипкина Л.Н., Щенникова Н.В. Полилингвиальность и транскультурные практики.

2018. T. 15. № 3. C. $354-371$

KPI 5.9. Number of student support programs:

5.9.1. - number of scholarship programs and programs of financial support for students.

Appendix 2

Section IV. Education and formation of the World elite.

Faculty of Social and Humanitarian studies

Task № 1

Development of upbringing potential of the learning process and of the upbringing role of teachers and chairs in work with students

Event № 1.3. Inclusion of general humanitarian topics in the curriculum; Interactive forms of teaching, organization of professional student competitions (the table also includes columns "responsible person"; "units of measurement", "results and timing").

\begin{tabular}{|l|l|}
\hline № & \multicolumn{1}{|c|}{ Goal } \\
\hline \multirow{2}{*}{1.3} & Inclusion of the following topics in the curriculum of humanitarian studies: \\
\cline { 2 - 2 } & History and geography of Russia; \\
\cline { 2 - 2 } & history and geography of students' countries of origin \\
\hline \multirow{2}{*}{ 1.3a } & Inclusion of general humanitarian topics in the curriculum \\
\cline { 2 - 2 } & Work and personal ethics of a professional \\
\cline { 2 - 2 } & RUDN's and its professors', teachers' and alumni's history and achievements \\
\cline { 2 - 2 } & Work ethics \\
\cline { 2 - 2 } & Characteristic traits of the major class in students' country of origin \\
\hline 1.3.B & Organization of professional student competitions \\
\hline 1.3c & Students' participation in professional competitions outside the University \\
\hline 1.3.d & $\begin{array}{l}\text { Organization and completion of trainings of communication skills, conflict management, } \\
\text { intercultural communication and tolerance }\end{array}$ \\
\hline
\end{tabular}

\section{Task № 2}

Improvement of organization of faculty's and chairs' upbringing work

Event № 2.1. Inclusion of general humanitarian topics in the curriculum; Interactive forms of teaching, organization of professional student competitions

\begin{tabular}{|c|l|}
\hline $2.1 \mathrm{e}$ & Student project competition \\
\hline $2.1 \mathrm{f}$ & Publication by the chair of textbook "Higher school ethics" (V. Zvyck) \\
\hline
\end{tabular}

Event № 2.3. Developing activity of professional student unions

\begin{tabular}{|c|l|}
\hline 2.3 & Number of student unions \\
\hline $2.3 a$ & Participation of students of the Faculty in scholarship programs and competitions \\
\hline
\end{tabular}

Event № 2.4. Interactive events aimed at students' professional and corporative development

\begin{tabular}{|c|l|}
\hline $2.4 \mathrm{a}$ & $\begin{array}{l}\text { Number of meetings and master classes with celebrities from Russia and the rest of the world } \\
\text { and with prominent alumni }\end{array}$ \\
\hline $2.4 \mathrm{~b}$ & $\begin{array}{l}\text { Number of Profession days (according to specialization) tied to professional celebration days } \\
\text { etc. }\end{array}$ \\
\hline $2.4 \mathrm{c}$ & $\begin{array}{l}\text { Number of student participating in professional orientation activity outside the university } \\
\text { (exhibitions, schools etc.) }\end{array}$ \\
\hline
\end{tabular}




\section{Task № 3}

Development of an efficient system of academic and social adaptation of the students

Event № 3.2. Planning and implementation of a series of activities aimed at familiarizing foreign students and students from other cities of Russia with the city of Moscow.

Event № 3.4. Implementation of the program of orientation for first year students

\section{Task № 4}

Development of creative initiative of the students, their involvement in different types of social activity within and outside the University

Event № 4.1. Broadening the format of inter-cultural dialogue among students (in classes, in day-to day life and in social life).

4.1b $\quad$ Inclusion in the curriculum of general humanitarian courses "Rhetoric", "Art of speech"

Event № 4.2. Involving students in projects and competitions outside the University

4.2 Number of prizes won by students in different competitions outside the University, including: - Social and professional competitions;

- Creative competitions

\section{Task № 5}

Developing the motivation and supporting student and student union social activity

\begin{tabular}{|l|l}
$5.1 \mathrm{~b}$ & Organization of team building events for students and post-graduate students
\end{tabular}

Event № 5.5. Support for student organizations and activists

\begin{tabular}{l|l}
$5.5 a$ & Identifying leaders using social metrics
\end{tabular}

\section{Task № 6}

Development of modern IT resources and formats of interaction with students

Event № 6.1. Organization of interaction with students using IT resources including student media, corporate portal Office-365, online communities etc.

\begin{tabular}{|c|l|}
\hline $6.1 \mathrm{a}$ & Number of professional student online communities in each study year \\
\hline $6.1 \mathrm{~b}$ & Organization and maintenance of online communities of student professional unions \\
\hline $6.1 \mathrm{c}$ & Number of micro surveys completed on corporate portal Office-365 \\
\hline 6.2 & $\begin{array}{l}\text { Encouraging the usage by student unions of faculty and chairs' online resources for a widest } \\
\text { distribution of information about events }\end{array}$ \\
\hline
\end{tabular}




\section{Task № 7}

Fostering interaction with alumni and unions of alumni in foreign countries based on corporate identity "Alma Mater"

\begin{tabular}{|c|l|}
\hline $7.1 \mathrm{a}$ & Creation of the system of involving alumni in participation in international QS ratings \\
\hline $7.1 \mathrm{~b}$ & Continuous update of information in alumni database, including databases of the chairs \\
\hline 7.2 & Contribution to creation of online magazine "RUDN alumni" \\
\hline
\end{tabular}

\section{Appendix 3}

Example of Russian as a foreign language competition tasks.

1. On a class board is put a colourful poster with a mixture of syllables written on it. The task is to create the maximum number of words using the syllables within a time limit. Each team assigns a group of 2-3 people to the task. Attention: the words that can potentially be created must be known to students. The syllables should not trigger negative associations. It is necessary to exclude a chance of creating an unexpected bad word.

2. In a bag are put items used in a day-to-day life (for example: a hammer, a screwdriver, a chisel, a corkscrew, a can opener, a hair curler, a pin, knitting needles, a dough roller, a cork etc.) The participants approach one by one and without looking pull out one item. The task is to name the item and to explain what it is used for. The results can be very amusing when including items which were commonly used in the last century but less widespread in modern days (a detachable pan handler, a tea strainer, a thimble, a whisk etc.)

(C) Anipkina L.N., Shchennikova N.V., 2018

\section{REFERENCES}

1. Anipkina, L.N. 2001. Russian Language for Sociologists, Moscow, RUDN publishing. Print. (in Russ.)

2. Anipkina, L., and T. Romanova. 2007. Russian Language for Historians. Moscow. Print. (in Russ.)

3. Buzan, T. 2001. The Power of Creative Intelligence. 10 Ways to Tap into Your Creative Genius, London. Print.

4. Csikszentmihalyi, M. 2013. Creativity. The Psychology of Discovery and Invention, New York. Print.

5. Snyder, B. 2005. Save the Cat: the last book on screenwriting you'll ever need, Michigan: Michael Wiese Productions. Print.

\section{Article history:}

Received: 06.03.2018

Accepted: 12.06.2018

Moderator: S.V. Dmitryuk

Conflict of interests: none

\section{For citation:}

Anipkina, L.N., and N.V. Shchennikova. 2018. "On Education”: A Look From Higher School's Point of View". Polylinguality and Transcultural Practices, 15 (3), 354-371. DOI 10.22363/2618897X-2018-15-3-354-371

\section{Bio Notes:}

Lada Nikitichna Anipkina is a PhD, Assistant Professor, Assistant Professor at the Department of Russian Language and Intercultural Communication of the Faculty of Humanities and Social 
Sciences of Peoples’ Friendship University of Russia (RUDN University). E-mail: lada-i-dima@ mail.ru

Nina Viktorovna Shchennikova is a PhD, Senior Lecturer at the Department of Russian Language and Intercultural Communication of the Faculty of Humanities and Social Sciences of Peoples' Friendship University of Russia (RUDN University). E-mail: ninashenn@gmail.com

\title{
«О ВОСПИТАНИИ» В ВЫСШЕЙ ШКОЛЕ
}

\author{
Л.Н. Анипкина, Н.В. Щенникова \\ Российский университет дружбы народов (РУДН) \\ Российская Федерация, 117198, Москва, ул. Миклухо-Маклая, 6
}

\begin{abstract}
Статья посвящена проблеме образования и воспитания студентов во внеучебной деятельности. Авторы представляют методологические кейсы, основываясь на собственном многолетнем педагогическом опыте. Большое внимание уделено принципам наиболее эффективной организации внеучебной деятельности студентов. Настоящая работа - презентация годовой программы РУДН по воспитательному блоку. Ее эффективность подтверждена эмпирически.

Ключевые слова: воспитание, образовательный кейс, внеучебная деятельность, креативность
\end{abstract}

\section{История статьи:}

Поступила в редакцию: 06.03.2018

Принята к публикации: 12.06.2018

Модератор: С.В. Дмитрюк

Конфликт интересов: отсутствует

\section{Для цитирования:}

Анипкина Л.Н., Щенникова Н.В. «О воспитании» в высшей школе // Полилингвиальность и транскультурные практики. 2018. Т. 15. № 3. C. 354-371. DOI 10.22363/2618-897X-201815-3-354-371

\section{Сведения об авторах:}

Анипкина Лада Никитична - кандидат филологических наук, доцент кафедры русского языка и межкультурной коммуникации Российского университета дружбы народов. E-mail: lada-i-dima@mail.ru

Щенникова Нина Викторовна - кандидат филологических наук, старший преподаватель кафедры русского языка и межкультурной коммуникации Российского университета дружбы народов. E-mail: ninashenn@gmail.com 